JKT, 2017;8(2):62-72. Studi Pengetahuan, Diet, Aktifitas Fisik, Minum Obat Khartini Kaluku, Nurhaedar Jafar, Citrakesumasari

\title{
STUDI PENGETAHUAN, DIET, AKTIFITAS FISIK, MINUM OBAT DAN KADAR GLUKOSA DARAH PASIEN DIABETES MELITUS TIPE 2 SEBELUM DAN SETELAH PENDAMPINGAN GIZI DI PUSKESMAS RIJALI KOTA AMBON TAHUN 2012
}

The Study of Knowledge, Physical Activity, Diet, Medication and The Blood Glucose Levels of Diabetes Mellitus Patient's Before and after Nutritional Accompaniment in Rijali Ambon Health Center on 2012

\author{
Khartini Kaluku1, Nurhaedar Jafar ${ }^{2}$, Citrakesumasari ${ }^{2}$ \\ ${ }^{1}$ Jurusan Gizi Poltekkes Kemenkes Maluku, Jalan Laksdya Leo Wattimena, Negeri \\ Lama, Ambon \\ ${ }^{2}$ Program Studi Ilmu Gizi Fakultas Kesehatan Masyarakat Universitas Hasanuddin, Jalan Perintis \\ Kemerdekaan KM.10, Tamalanrea Indah, Kec. Tamalanrea, Kota Makassar, Sulawesi Selatan \\ E-mail:gz_thika@yahoo.com
}

\begin{abstract}
Diabetes mellitus has become the world's health problems. The prevalence and incidence of these diseases has increased drastically in the newly industrialized countries and developing countries, including Indonesia's. This research is an experimental research by approach nonrandomized one group pre and posttest design which is to see the difference knowledge, diet, physical activity, medication and the patient's blood glucose levels diabetes mellitus before and after accompaniment nutrition in Puskesmas Rijali Ambon. The population of this research is all patients diabetes mellitus, sampling is done by using the technique of purposive sampling with the total sample as many as 26 people. The result showed that after the accompaniment of nutrition increase knowledge 42,3\%, compliance intake of energy $23,1 \%$, compliance intake of proteins $23.1 \%$, compliance fat intake $38.5 \%$, compliance intake of carbohydrates $3.9 \%$, compliance physical activity $30,8 \%$, compliance medication $30,8 \%$ and blood glucose levels are $42,3 \%$. Attesting four main pillars handling DM use the model of nutritional accompaniment give a flanking control blood sugar of $70 \%$. Of the results obtained, can be concluded that the educational model counselling of nutrition is very influential to increase knowledge and compliance respondents against the diet, physical activity, medication and blood glucose levels.
\end{abstract}

Keywords: Blood glucose levels, diet, knowledge, diet, medication, physical activity

\section{ABSTRAK}

Penyakit diabetes mellitus telah menjadi masalah kesehatan dunia. Prevalensi dan insiden penyakit ini meningkat secara drastis di negara industri baru dan negara sedang berkembang, termasuk Indonesia. Penelitian ini merupakan penelitian eksperimental dengan pendekatan non randomized one group pre and posttest design yang bertujuan untuk melihat perbedaan pengetahuan, diet, aktifitas fisik, minum obat dan kadar glukosa darah pasien Diabetes Melitus sebelum dan setelah pendampingan gizi di Puskesmas Rijali Kota Ambon. Populasi dalam penelitian ini adalah semua pasien Diabetes Melitus, pengambilan sampel dilakukan dengan menggunakan teknik purposive sampling dengan jumlah sampel sebanyak 26 orang. Hasil penelitian menunjukkan bahwa setelah dilakukan pendampingan gizi terjadi peningkatan pengetahuan $42,3 \%$, kepatuhan asupan energi $23,1 \%$, kepatuhan asupan protein $23,1 \%$, kepatuhan asupan lemak 38,5\%, kepatuhan asupan karbohidrat 3,9\%, kepatuhan aktifitas fisik 30,8\%, kepatuhan minum obat 30,8\% dan kadar glukosa darah sewaktu 42,3\%. Pembuktian 4 Pilar penanganan DM menggunakan model pendampingan gizi memberikan hasil pengendalian kadar gula darah sewaktu sebesar 70\%. Edukasi model pendampingan gizi berpengaruh untuk meningkatkan pengetahuan dan kepatuhan responden terhadap diet, aktifitas fisik dan minum obat serta mengendalikan kadar glukosa darah. Dokter dan Ahli Gizi diharapkan bekerjasama memberikan konsultasi gizi agar pasien mengetahui tentang penatalaksanaan Diabetes Melitus sehingga pasien dapat merawat diri secara mandiri dan benar, serta melanjutkan program pendampingan gizi untuk memantau kadar gula darah pasien.

Kata kunci: Aktifitas fisik, diet, kadar glukosa darah, minum obat, pengetahuan 
JKT, 2017;8(2):62-72. Studi Pengetahuan, Diet, Aktifitas Fisik, Minum Obat Khartini Kaluku, Nurhaedar Jafar, Citrakesumasari

\section{PENDAHULUAN}

Pembangunan kesehatan Indonesia diarahkan guna mencapai pemecahan masalah kesehatan untuk hidup sehat bagi setiap penduduk agar dapat mewujudkan derajat kesehatan yang optimal. Masalah kesehatan dapat dipengaruhi oleh pola hidup, pola makan, lingkungan kerja, olahraga dan stres. Perubahan gaya hidup terutama di kota-kota besar, menyebabkan meningkatnya prevalensi penyakit degeneratif, seperti penyakit jantung, hipertensi, hiperlipidemia, diabetes melitus (DM) dan lain-lain ${ }^{1}$.

Prevalensi global: Jumlah kasus diabetes di seluruh dunia pada tahun 2000 di kalangan orang dewasa (20 tahun) diperkirakan 171 juta dan akan meningkat menjadi 366 juta pada 2030 (Wild et al. 2009). Dalam hal peringkat negara-negara untuk prevalensi T2DM, Ukraina (3,2 juta) adalah di bagian bawah daftar, Pakistan (5,2 juta) datang pada nomor enam, Cina adalah kedua dengan 20,8 juta orang dan India memiliki jumlah tertinggi (31,7 juta) orang dengan tingkat 3\% untuk T2DM. Para Pima Indian Arizona di Amerika Serikat (AS) dan memiliki tingkat prevalensi tertinggi $(21 \%)$ dari T2DM ${ }^{2}$.

Hasil penelitian epidemiologis 1993 di Jakarta (daerah urban) membuktikan adanya peningkatan prevalensi DM dari 1,7\% pada tahuan 1982 menjadi 5,7\% pada tahun 1993, kemudian pada tahun 2001 di Depok, daerah sub-urban di selatan Jakarta menjadi 12,8\%. Demikian pula prevalensi di Ujung Pandang (daerah urban), meningkat dari 1,5\% pada tahun 1981 menjadi 3,5\% pada tahun 1998 dan terakhir pada tahun 2005 menjadi 12,5\% ${ }^{3}$.

Dalam pengelolaan diabetes, langkah pertama yang harus dilakukan adalah pengelolaan secara non farmakologis yaitu perencanaan diet, aktivitas fisik, dan penyuluhan. Jika pengendalian kadar glukosa dengan cara ini tidak tercapai, maka langkah selanjutnya adalah pengelolaan farmakologis atau penggunaan obat ${ }^{4}$.

Pengetahuan gizi merupakan faktor yang sangat penting dalam menentukan sikap dan perilaku seseorang terhadap makanan. Selain itu pengetahuan gizi merupakan peranan penting untuk dapat membuat manusia hidup sehat sejahtera dan berkualitas. Gizi mempunyai hubungan langsung dengan tingkat konsumsi tetapi secara langsung mencerminkan tingkat pengetahuan ${ }^{5}$.

Pendampingan di bidang gizi dan kesehatan adalah salah satu bentuk penyuluhan yang bersifat intensif lewat tatap muka harian. Edukasi dengan menggunakan metode pendampingan dinilai lebih efektif dibandingkan metode penyuluhan konvensional ${ }^{6}$.

Pasien Diabetes Melitus di Puskesmas Rijali diperoleh data pada bulan Januari - Desember 2011 sebanyak 328 orang. Di Puskesmas Rijali pengelolaan penderita Diabetes Melitus selama ini hanya sebatas pada pengelolaan secara farmakologis yakni penggunaan obat. Pengelolaan secara non farmakologis yaitu edukasi/penyuluhan, perencanaan diet, dan aktivitas fisik belum dilakukan secara maksimal. Berdasarkan uraian tersebut diatas maka peneliti tertarik untuk melakukan edukasi dengan metode pendampingan gizi terhadap penderita Diabetes Melitus Tipe 2 di Wilayah kerja Puskesmas Rijali Kota Ambon Tahun 2012.

\section{METODE PENELITIAN}

Penelitian ini dilaksanakan di Puskesmas Rijali Kota Ambon. Jenis penelitian ini adalah penelitian eksperimen dengan pendekatan One Group Pretest And Postest Design. Penelitian ini dilakukan secara perorangan dengan indepth interview. Dengan maksud untuk mengetahui perubahan peningkatan pengetahuan, kepatuhan diet, aktifitas fisik, minum obat dan kadar gula darah pasien Diabetes Melitus tipe 2 setelah pendampingan gizi. Penelitian dilakukan selama 30 hari setiap responden dikunjungi sebanyak 4x selama 3 minggu dan post test pada hari ke28 setelah pendampingan gizi. Variabel penelitian ini adalah pengetahuan, diet, aktifitas fisik, minum obat dan kadar gula darah pasien DM tipe 2.

Populasi dalam penelitian ini semua Pasien Diabetes Melitus yang datang berkunjung ke Puskesmas Rijali Kota Ambon pada bulan Februari s/d Maret 2012. Sampel adalah seluruh Pasien Diabetes Melitus yang datang memeriksakan diri ke Puskesmas Rijali Kota Ambon yang 
JKT, 2017;8(2):62-72. Studi Pengetahuan, Diet, Aktifitas Fisik, Minum Obat

Khartini Kaluku, Nurhaedar Jafar, Citrakesumasari

terpilih sebagai responden dan bersedia diwawancarai dengan sampel 26 orang. Teknik pengambilan sampel yaitu dengan metode purposive sampling.

Data primer yaitu data identitas dan karakteristik responden (umur, jenis kelamin, sosial ekonomi, pendidikan, riwayat menderita DM dan jenis obat), kepatuhan diet, aktivitas fisik, Berat Badan (BB) dan Tinggi Badan (TB) yang akan digunakan untuk menghitung kebutuhan kalori pasien dan kadar gula darah pasien dengan menggunakan glucodr. Dan data Sekunder yaitu gambaran umum Puskesmas Rijali Kota Ambon.

Data hasil penelitian diperoleh dengan observasi dan wawancara, kemudian diolah secara manual dan dengan menggunakan program Nutrisurvey, Microsoft Excel dan SPSS.

\section{HASIL}

Di Puskemas Rijali pada tahun 2011 didapatkan 328 kunjungan pasien Diabetes Melitus yaitu rata-rata 26/bulan. Di dalam Pengelolaan DM terdapat 4 pilar utama yaitu perencanaan makan, latihan jasmani, obat berkhasiat hipoglikemik dan penyuluhan/edukasi gizi. Dalam penanganan Diabetes Melitus di Puskesmas ini dilakukan Health Education yaitu mengenai edukasi penggunaan obat tetapi tidak melakukan Edukasi Gizi. Berdasarkan keterangan yang didapatkan pasien ditangani seperti pasien biasa yaitu hanya dilakukan kontrol gula darah dan diberikan obat.

\section{Karakteristik Sampel}

Tabel 1. Distribusi Responden Berdasarkan Karakteristik Responden di Puskesmas Rijali Kota Ambon Tahun 2012

\begin{tabular}{|c|c|c|}
\hline Karakteristik & n (26) & $\%$ \\
\hline \multicolumn{3}{|l|}{ Jenis Kelamin } \\
\hline _ Laki-laki & 4 & 15,4 \\
\hline - Perempuan & 22 & 84,6 \\
\hline \multicolumn{3}{|l|}{ Kelompok Umur (Tahun) } \\
\hline$-30-44$ & 5 & 19,2 \\
\hline$-\quad 45-59$ & 12 & 46,2 \\
\hline$-\quad \geq 60$ & 9 & 34,6 \\
\hline \multicolumn{3}{|l|}{ Pekerjaan } \\
\hline - PNS & 6 & 23,1 \\
\hline - Pegawai Swasta & 3 & 11,5 \\
\hline - Pedagang & 4 & 15,4 \\
\hline - IRT & 12 & 46,2 \\
\hline - Buruh & 1 & 3,8 \\
\hline \multicolumn{3}{|l|}{ Pendidikan } \\
\hline - Pendidikan Dasar & 10 & 38,5 \\
\hline - SMA & 10 & 38,5 \\
\hline - Diploma/Sarjana & 6 & 23,0 \\
\hline \multicolumn{3}{|l|}{ Lama Menderita DM } \\
\hline$-1-5$ tahun & 20 & 76,9 \\
\hline$->5$ tahun & 6 & 23,1 \\
\hline \multicolumn{3}{|l|}{ Pernah Dapat Penyuluhan } \\
\hline$-\mathrm{Ya}$ & 5 & 19,2 \\
\hline - Tidak & 21 & 80,8 \\
\hline
\end{tabular}

Sumber : Data Primer, 2012 
JKT, 2017;8(2):62-72. Studi Pengetahuan, Diet, Aktifitas Fisik, Minum Obat

Khartini Kaluku, Nurhaedar Jafar, Citrakesumasari

Karakteristik sampel yang diteliti dapat dilihat pada Tabel 1 menunjukkan bahwa jumlah responden sebagian besar yang berjenis kelamin perempuan sebanyak 22 responden $(84,6 \%)$. Berdasarkan kelompok umur yang terbanyak menderita Diabetes Melitus Tipe 2 ada pada kelompok umur 45-59 tahun yaitu 12 responden (46,2\%). Pada kelompok pekerjaan yang terbanyak yang menderita Diabetes Melitus Tipe 2 ada pada kelompok pekerjaan IRT (ibu rumah tangga) yaitu 12 responden $(46,2 \%)$.

Pasien DM tipe 2 rata-rata ada pada tingkat pendidikan dasar (SD dan SMP) dan SMA masing-masing sebanyak 10 responden $(46,2 \%)$, berdasarkan lama menderita yang terbanyak ada pada $1-5$ tahun yaitu 20 responden $(76,9 \%)$. Rata-rata responden tidak mendapatkan penyuluhan sebanyak $80,8 \%$.

\section{Pengetahuan}

Tabel 2. Distribusi Pengetahuan Terhadap Kadar Gula Darah Sewaktu (GDS) Pasien DM Tipe 2 Puskesmas Rijali Kota Ambon Tahun 2012

\begin{tabular}{ccccccc}
\hline & \multicolumn{2}{c}{ Kriteria Kadar Gula Darah Sewaktu } & \multicolumn{2}{c}{ Total } \\
Pengetahuan & \multicolumn{2}{c}{ Terkendali } & \multicolumn{2}{c}{ Tidak Terkendali } & \multicolumn{2}{c}{ Total } \\
& n & \% & n & \% & n & \% \\
\hline Sebelum & & & & & & \\
Cukup $(\geq 75 \%)$ & 2 & 13,3 & 13 & 86,7 & 15 & 57,7 \\
Kurang $(<75 \%)$ & 3 & 27,3 & 8 & 72,7 & 11 & 42,3 \\
Total & 5 & 19,2 & 21 & 80,8 & 26 & 100 \\
Sesudah & & & & & & \\
Cukup $(\geq 75 \%)$ & 16 & 61,5 & 10 & 38,5 & 26 & 100 \\
Kurang $(<75 \%)$ & 0 & 0,0 & 0 & 0,0 & 0 & 0,0 \\
Total & 16 & 61,5 & 10 & 38,5 & 26 & 100 \\
\hline
\end{tabular}

Sumber: Data Primer,2012

Berdasarkan hasil pre-test didapatkan bahwa tingkat pengetahuan responden sebelum diberikan edukasi adalah sebanyak 11 orang $(42,3 \%)$ pada kategori kurang, dan ada 15 orang $(57,7 \%)$ berkategori baik. Kemudian, setelah dilakukan pendampingan gizi terjadi peningkatan pengetahuan sebesar 42,3\% sehingga 100\% berkategori cukup (Gambar 1).

Tabel 2 menunjukkan bahwa pada pertanyaan no.15 adalah pertanyaan yang paling sedikit dijawab benar (50\%) sebelum pendampingan. Sehingga pada saat pendampingan gizi responden diberi edukasi tentang 4 pilar penanganan DM serta perencanaan diet khusus untuk penderita DM tipe 2. Dan pada saat post-test telah mengalami peningkatan menjadi $96 \%$. 
JKT, 2017;8(2):62-72. Studi Pengetahuan, Diet, Aktifitas Fisik, Minum Obat

Khartini Kaluku, Nurhaedar Jafar, Citrakesumasari

\section{Kepatuhan Diet}

Tabel 3. Distribusi Kepatuhan Diet Terhadap Kadar Gula Darah Sewaktu (GDS) Pasien DM Tipe 2 Puskesmas Rijali Kota Ambon Tahun 2012

\begin{tabular}{|c|c|c|c|c|c|c|}
\hline \multirow{3}{*}{ Asupan } & \multicolumn{4}{|c|}{ Kriteria Kadar Gula Darah Sewaktu } & \multirow{2}{*}{\multicolumn{2}{|c|}{ Total }} \\
\hline & \multicolumn{2}{|c|}{ Terkendali } & \multicolumn{2}{|c|}{ Tidak Terkendali } & & \\
\hline & $\mathbf{n}$ & $\%$ & $\mathbf{n}$ & $\%$ & $\mathbf{n}$ & $\%$ \\
\hline $\begin{array}{c}\text { Sebelum Pendampingan Gizi } \\
\text { Energi }\end{array}$ & & & & & & \\
\hline Patuh $(75 \%-100 \%)$ & 2 & 14,3 & 12 & 85,7 & 14 & 43,8 \\
\hline Tidak Patuh $(<75 \%$ / >100\%) & 3 & 25,0 & 9 & 75,0 & 12 & 46,2 \\
\hline Protein & & & & & & \\
\hline Patuh $(10 \%-20 \%$ Kkal $)$ & 3 & 21,4 & 11 & 78,6 & 14 & 53,8 \\
\hline $\begin{array}{c}\text { Tidak Patuh }(<10 \% \text { / >20\% Kkal }) \\
\text { Lemak }\end{array}$ & 2 & 16,7 & 10 & 83,3 & 12 & 46,2 \\
\hline Patuh $(20 \%-25 \%$ Kkal $)$ & 2 & 66,7 & 1 & 33,3 & 3 & 11,5 \\
\hline $\begin{array}{c}\text { Tidak Patuh }(<20 \% \text { / >25\% Kkal }) \\
\text { Karbohidrat }\end{array}$ & 3 & 13,0 & 20 & 87,0 & 23 & 88,5 \\
\hline Patuh $(45 \%-65 \%$ Kkal $)$ & 1 & 11,1 & 8 & 88,9 & 9 & 34,6 \\
\hline Tidak Patuh $(<45 \%$ / >65\% Kkal $)$ & 4 & 23,5 & 13 & 76,5 & 17 & 65,4 \\
\hline Total & 5 & 19,2 & 21 & 80,8 & 26 & 100 \\
\hline $\begin{array}{c}\text { Setelah Pendampingan Gizi } \\
\text { Energi }\end{array}$ & & & & & & \\
\hline Patuh $(75 \%-100 \%)$ & 14 & 70,0 & 6 & 30,0 & 20 & 76,9 \\
\hline $\begin{array}{c}\text { Tidak Patuh }(<75 \% />100 \%) \\
\text { Protein }\end{array}$ & 2 & 33,3 & 4 & 66,7 & 6 & 23,1 \\
\hline Patuh $(10 \%-20 \%$ Kkal) & 15 & 62,5 & 9 & 37,5 & 24 & 92,3 \\
\hline $\begin{array}{c}\text { Tidak Patuh }(<10 \% \text { / >20\% Kkal }) \\
\text { Lemak }\end{array}$ & 1 & 50,0 & 1 & 50,0 & 2 & 7,7 \\
\hline Patuh $(20 \%-25 \%$ Kkal $)$ & 9 & 69,2 & 4 & 30,8 & 13 & 50,0 \\
\hline $\begin{array}{c}\text { Tidak Patuh }(<20 \% \text { / >25\% Kkal }) \\
\text { Karbohidrat }\end{array}$ & 7 & 53,8 & 6 & 46,2 & 13 & 50,0 \\
\hline Patuh $(45 \%-65 \%$ Kkal $)$ & 7 & 70,0 & 3 & 30,0 & 10 & 38,5 \\
\hline Tidak Patuh $(<45 \%$ / >65\% Kkal $)$ & 9 & 56,2 & 7 & 43,8 & 16 & 61,5 \\
\hline Total & 16 & 61,5 & 10 & 38,5 & 26 & 100 \\
\hline
\end{tabular}

Sumber: Data Primer,2012

Setelah dilakukan pendampingan gizi terjadi peningkatan kepatuhan diet pada asupan energi dari 53,8\% menjadi 76,9\%, peningkatan asupan protein sebesar dari 53,8\% menjadi $76,9 \%$, peningkatan asupan lemak sebesar dari $11,5 \%$ menjadi $50 \%$ serta peningkatan asupan karbohidrat sebesar dari 34,6 menjadi 38,5. 
JKT, 2017;8(2):62-72. Studi Pengetahuan, Diet, Aktifitas Fisik, Minum Obat Khartini Kaluku, Nurhaedar Jafar, Citrakesumasari

\section{Aktifitas Fisik}

Tabel 4. Distribusi Aktifitas Fisik Terhadap Kadar Gula Darah Sewaktu (GDS) Pasien DM Tipe 2 Puskesmas Rijali Kota Ambon Tahun 2012

\begin{tabular}{|c|c|c|c|c|c|c|}
\hline \multirow{3}{*}{ Aktifitas Fisik } & \multicolumn{4}{|c|}{ Kriteria Kadar Gula Darah Sewaktu } & \multirow{2}{*}{\multicolumn{2}{|c|}{ Total }} \\
\hline & \multicolumn{2}{|c|}{ Terkendali } & \multicolumn{2}{|c|}{ Tidak Terkendali } & & \\
\hline & $\mathbf{n}$ & $\%$ & $\mathbf{n}$ & $\%$ & \multicolumn{2}{|c|}{ n $\%$} \\
\hline Sebelum & & & & & & \\
\hline Patuh (Olahraga 3-60 menit/hari) & 4 & 22,2 & 14 & 77,8 & 18 & 69,2 \\
\hline Tidak Patuh (Olahraga tidak rutin) & 1 & 12,5 & 7 & 87,5 & 8 & 30,8 \\
\hline Total & 5 & 19,2 & 21 & 80,8 & 26 & 100 \\
\hline Sesudah & & & & & & \\
\hline Patuh (Olahraga 30-60 menit/hari) & 16 & 61,5 & 10 & 38,5 & 26 & 100 \\
\hline Tidak Patuh (Olahraga tidak rutin) & 0 & 0,0 & 0 & 0,0 & 0 & 0,0 \\
\hline Total & 16 & 61,5 & 10 & 38,5 & 26 & 100 \\
\hline
\end{tabular}

Sumber: Data Primer,2012

Terjadi perubahan peningkatan aktifitas fisik sebesar $30,8 \%$ setelah dilakukan pendampingan gizi dari $69,2 \%$ menjadi $100 \%$.

Kepatuhan Minum Obat

Tabel 5. Distribusi Minum Obat Terhadap Kadar Gula Darah Sewaktu (GDS) Pasien DM Tipe 2 Puskesmas Rijali Kota Ambon Tahun 2012

\begin{tabular}{ccccccc}
\hline & \multicolumn{2}{c}{$\begin{array}{c}\text { Kriteria Kadar Gula Darah Sewaktu } \\
\text { Minum Obat }\end{array}$} & $\begin{array}{c}\text { Terkendali } \\
\text { n }\end{array}$ & $\mathbf{\%}$ & $\begin{array}{c}\text { Tidak Terkendali } \\
\text { n }\end{array}$ & \multicolumn{2}{c}{ Total } & n & \% \\
\hline Sebelum & & & & & & \\
Patuh (Sesuai anjuran dokter) & 5 & 27,8 & 13 & 72,2 & 18 & 69,2 \\
Tidak Patuh (Tidak sesuai anjuran) & 0 & 0,0 & 8 & 100 & 8 & 30,8 \\
Total & 5 & 19,2 & 21 & 80,8 & 26 & 100 \\
Sesudah & & & & & & \\
Patuh (Sesuai anjuran dokter) & 16 & 61,5 & 10 & 38,5 & 26 & 100 \\
Tidak Patuh (Tidak sesuai anjuran) & 0 & 0,0 & 0 & 0,0 & 0 & 0,0 \\
Total & 16 & 61,5 & 10 & 38,5 & 26 & 100 \\
\hline
\end{tabular}

Sumber: Data Primer,2012

Terjadi peningkatan kepatuhan minum obat sebesar dari 69,2 menjadi $100 \%$ setelah dilakukan pendampingan gizi.

\section{Kadar Glukosa Darah Sewaktu}

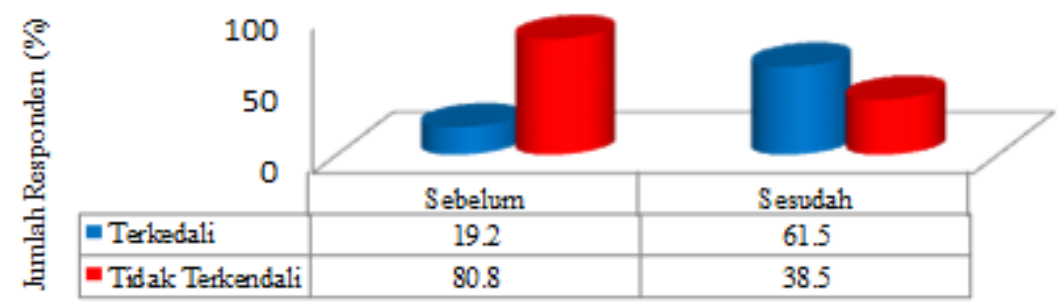

Gambar 1. Grafik Kadar Gula Darah Sebelum Dan Setelah Edukasi Gizi 
JKT, 2017;8(2):62-72. Studi Pengetahuan, Diet, Aktifitas Fisik, Minum Obat Khartini Kaluku, Nurhaedar Jafar, Citrakesumasari

Setelah dilakukan pendampingan gizi terjadi peningkatan kadar glukosa darah sewaktu sebesar $42,3 \%$, yaitu dari $19,2 \%$ menjadi $61,5 \%$.

\section{BAHASAN}

\section{Perbedaan Pengetahuan Sebelum Dan Setelah Pendampingan Gizi}

Berdasarkan hasil penelitian terjadi peningkatan pengetahuan setelah pendampingan gizi sebesar $42,3 \%$. Sehingga semua responden (100\%) pada saat post-test berpengetahuan cukup. Hal ini sejalan dengan penelitian yang dilakukan oleh Amir, $2011^{6}$ tentang pengaruh penyuluhan model pendampingan menunjukan hasil yang signifikan terhadap peningkatan pengetahuan ibu, tingkat konsusmi, pola asuh anak dan perubahan status gizi baduta di propinsi Sulawesi Selatan. Hasil penelitian tersebut menunjukan bahwa penyuluhan model pendampingan lebih efektif dari pada penyuluhan konvensional yang dilakukan setiap bulan di Posyandu dalam menekan penurunan status gizi anak usia 6-24 bulan.

Dari hasil sebelum dilakukan pendampingan gizi responden sudah lebih banyak yang berkategori cukup sebanyak 15 responden $(57,7 \%)$. Berdasarkan keterangan yang didapatkan pasien mendapatkan informasi mengenai diabetes ada yang berasal dari penyuluhan dari rumah sakit, majalah, surat kabar dan televisi. Hal ini sesuai dengan yang dikatakan Azwar $2007^{7}$ yaitu dengan majunya teknologi akan tersedia pula bermacam-macam media masa yang dapat pula mempengaruhi pengetahuan masyarakat. Sedangkan setelah post-test, semua kelompok umur mempunyai kategori pengetahuan baik (100\%). Hal ini dikarenakan juga selain diberikan pendampingan gizi juga diberikan edukasi dan bahan rujukan berupa print out dan booklet yang berisikan dari materi edukasi gizi yang diberikan. Sehingga dapat dibaca kembali dan dapat meningkatkan dan mempertahankan pengetahuan yang didapatkan melalui edukasi tersebut.

Dengan semakin baik dan luasnya pengetahuan responden maka diharapkan semakin baik pula pengetahuannya terhadap gizi dan kesehatan, khususnya dalam hal bahan makanan yang baik untuk dikonsumsi. Hal ini selaras dengan yang dikatakan Sediaoetama 1987, bahwa semakin banyak pengetahuan gizinya, semakin diperhitungkan jenis dan kuantum makananan yang dipilih untuk dikonsumsinya. Awam yang tidak mempunyai cukup pengetahuan gizi, akan memilih makanan yang paling menarik panca indera, dan tidak mengadakan pilihan berdasarkan nilai gizi makanan. Sebaliknya mereka yang semakin banyak pengetahuan gizinya, lebih banyak mempergunakan pertimbangan rasional dan pengetahuan tentang nilai gizi makanan tersebut ${ }^{8}$.

Jika dilihat dari tabulasi silang pengetahuan dengan kadar Gula Darah Sewaktu (GDS) responden didapatkan bahwa pada pengetahuan memberikan kontribusi sebesar $48,2 \%$ bagi terkendalinya kadar GDS responden setelah pendampingan gizi.

Hal ini di dukung oleh pendapat Day dan Assal yang menyatakan bahwa monitor kadar glukosa darah merupakan hal utama dalam pengelolaan penyakit DM melalui penyuluhan/konsultasi agar dapat memahami hubungan antara pengendalian kadar glukosa darah dengan pengaturan makan, olah raga dan berobat secara teratur. Sejalan dengan pendapat tersebut di atas, Philips melaporkan bahwa responden DM tipe 2 yang diberi penyuluhan terpadu selama dua tahun ternyata menunjukkan adanya peningkatan skor pengetahuan (58\%) dan perbaikan kadar gula darah (34\%) dibanding sebelum dilakukan penyuluhan ${ }^{9}$.

Perbedaan Kepatuhan Diet Sebelum Dan Setelah Pendampingan Gizi

Setelah dilakukan pendampingan gizi terjadi peningkatan kepatuhan diet pada asupan energi sebesar 23,1\% dan memberikan kontribusi untuk GDS terkendali sebesar 55,7\%, peningkatan asupan protein sebesar $23,1 \%$ dan memberikan kontribusi untuk GDS terkendali sebesar $41,1 \%$, peningkatan asupan lemak sebesar 38,5\% dan memberikan kontribusi untuk GDS terkendali sebesar 2,5\% serta peningkatan asupan karbohidrat sebesar 3,9\% dan memberikan kontribusi untuk GDS terkendali sebesar 58,9\%. Masih adanya pasien diabetes tidak patuh terhadap kepatuhan diet yang dianjurkan dipengaruhi oleh beberapa faktor yaitu sesuai hasil wawancara mendalam dengan beberapa responden tentang alasan tidak patuh diet seperti responden yang tidak dapat mengontrol makanannya seperti sering mengemil, tidak bisa 
JKT, 2017;8(2):62-72. Studi Pengetahuan, Diet, Aktifitas Fisik, Minum Obat

Khartini Kaluku, Nurhaedar Jafar, Citrakesumasari

mengurangi porsi makan nasi, mengikut pola makan keluarga, kurang nafsu makan, dan pada saat ada pesta makannya jadi tidak terkendali.

Hal ini sesuai dengan pernyataan Abduracchim $2008^{10}$ ketidakpatuhan menjalankan diet dapat disebabkan karena beberapa alasan yaitu tidak dapat mengendalikan nafsu makan, merasa telah terkontrol gula darahnya karena pemberian obat diabetes dari dokter, sehingga merasa tidak perlu menjalankan diet dengan baik. Selain itu pendapat kurang mendukung untuk memenuhi konsumsi bahan makanan dengan kualitas dan kuantitas yang baik dan juga alasan kesibukan bekerja, sehingga tidak dapat mengatur waktu yang tepat untuk makan sesuai jadwal, jumlah maupun jenis dari bahan makanan yang boleh dan tidak boleh untuk dikonsumsi.

Hal ini juga sesuai dengan pendapat Moda dkk $2012^{11}$ yaitu faktor budaya yang mempengaruhi perilaku pola makan responden, serta faktor-faktor yang dihubungkan dengan kepribadian responden seperti; motivasi dan niat dari dalam diri responden, kembalinya responden ke pola makan awal karena merasa kondisi tubuhnya sudah baik sehingga kontrol dirinya berkurang, dan belum mampu menerapkan proporsi zat gizi yang dikonsumsi sesuai dengan anjuran.

Terjadinya peningkatan kepatuhan diet yang diberikan oleh responden ini disebabkan karena edukasi yang diberikan tidak hanya mengenai penjelasan mengatur diet tetapi diberikan pula pengaturan diet yang jelas takarannya yang dapat dilihat dari booklet dan print out slide yang diberikan sehingga pasien dapat mengatur pola makannnya dengan melihatnya. Dan karena edukasi ini diberikan secara perorangan yaitu melalui kunjungan rumah responden sehingga keluarga yang ada di rumahnya pun ikut berperan. Hal ini dilihat dari antusias keluarga responden ikut dalam edukasi yang diberikan oleh responden sehingga faktor keluarga pun merupakan faktor yang dapat meningkatakan kepatuhan. Hal ini sejalan dengan pernyataan Moda dkk, $2012^{11}$ yaitu faktor lingkungan dapat meningkatkan kepatuhan diet meliputi adanya dukungan dari keluarga, namun jika yang menyiapkan makanan responden adalah orang lain/keluarga yang tidak mengikuti kegiatan penyuluhan, jumlah serta bahan makanan yang disajikan tidak sesuai dengan anjuran diet. Selain diberikan edukasi juga dilakukan pemeriksaan gula darah sehingga meningkatkan minat pasien dalam melakukan pengaturan makan.

Hal ini sejalan dengan penelitian Chabchoub $2000^{12}$ menunjukkan bahwa korelasi negatif yang signifikan antara asupan energi total dan jumlah karbohidrat $(r=-0,46, p<0,01)$ dan protein $(r=-0,70, p<0,01)$, sementara itu positif antara pertama dan lipid asupan $(r=0,63, p$ $<0,01$ ) setelah dilakukan edukasi gizi. Dan menurut Husain $2010^{13}$ menunjukkan tidak ada beda rata-rata yang signifikan pada intake energi dan zat gizi responden $(\rho<0.05)$, rata-rata intake energi dan zat gizi responden pada hari ke 14 cenderung meningkat namun tidak melebihi batas normal anjuran. Dan penelitian Siddiqui $2010^{14}$ yang menunjukkan kepatuhan secara keseluruhan untuk konseling diet sangat baik sebesar 19,4\% baik 37,5\%, baik sebesar 33,3\% dan kurang sebesar 9,7\%. Menurut Sackett dalam Niven, kepatuhan adalah sejauh mana perilaku pasien sesuai dengan ketentuan yang diberikan oleh professional kesehatan. Kepatuhan pasien berkenaan dengan kemauan dan kemampuan dari individu untuk mengikuti cara sehat yang berkaitan dengan nasehat aturan pengobatan yang ditetapkan mengikuti jadwal pemeriksaan dan rekomendasi hasil penyelidikan. Kepatuhan juga merupakan tingkat perilaku penderita dalam mengambil suatu tindakan untuk pengobatan seperti diet, kebiasaan hidup sehat dan ketetapan berobat. Sikap perilaku individu dimulai dengan tahap kepatuhan, identifikasi, kemudian menjadi internalisasi ${ }^{15}$.

Diet merupakan faktor kunci dalam mengendalikan diabetes. Diet terapi adalah komponen penting dari pengobatan dan dapat mengakibatkan biaya yang lebih rendah dari disease. Karena pasien memiliki peran utama dalam kontrol dan pengobatan diabetes tipe 2 , itu adalah penting untuk menyediakan mereka dengan manajemen edukasi dan terapi diet diri sendiri. Pentingnya edukasi ini tergantung pada dampak perilaku tersebut ${ }^{13}$.

\section{Perbedaan Aktifitas Fisik Sebelum Dan Setelah Pendampingan Gizi}


JKT, 2017;8(2):62-72. Studi Pengetahuan, Diet, Aktifitas Fisik, Minum Obat Khartini Kaluku, Nurhaedar Jafar, Citrakesumasari

Berdasarkan penelitian yang dilakukan diperoleh hasil bahwa terjadi perubahan sebesar 30,8\% kepatuhan aktifitas fisik setelah pendampingan gizi dan sebanyak 39,3\% memberikan kontribusi terhadap terkendalinya kadar GDS. Hal ini terjadi karena sebagian besar responden yang didampingi telah mampu menerapkan anjuran berolah raga seperti jalan cepat selama minimal 30-60 menit secara rutin 3-4x/minggu.

Hal ini sejalan dengan pengelolaan diabetes, dimana latihan jasmani yang teratur memegang peran penting terutama pada Diabetes melitus tipe 2. Manfaat latihan jasmani yang teratur pada diabetes antara lain adalah memperbaiki metabolisme; menormalkan kadar glukosa darah dan lipid darah, meningkatkan kerja insulin, membantu menurunkan berat badan, meningkatkan kesegaran jasmani, dan mengurangi resiko penyakit kardiovaskular. Kegiatan jasmani yang kurang merupakan salah satu resiko penyebab terjadinya DM tipe 2. Kurangnya kegiatan jasmani dapat mempengaruhi kerja insulin pada tingkat reseptor yang dapat mengakibatkan terjadinya resistensi insulin sehingga timbul DM tipe $2^{16}$.

\section{Perbedaan Kepatuhan Minum Obat Sebelum Dan Setelah Pendampingan Gizi}

Berdasarkan penelitian yang dilakukan diperoleh hasil bahwa terjadi perubahan sebesar $30,8 \%$ kepatuhan minum obat setelah pendampingan gizi dan hasil tabulasi silang antara minum obat dengan terkendalinya kadar GDS responden diperoleh sebanyak 33,7\%. Berdasarkan hasil wawancara dan pemantauan ditemukan bahwa semua responden hanya mengkonsumsi obat dari Puskesmas saja dengan jenis OHO berupa Glibenclamid dan Metformin. Setelah pendampingan semua responden patuh minum obat sesuai anjuran dokter untuk tepat dosis dan tepat waktu.

Pemberian obat kepada pasien sesuai petunjuk dokter merupakan suatu tindakan/ praktek kesehatan yang dilakukan dalam rangka pemeliharaan dan peningkatan kesehatan sebagai bagian dari perilaku seseorang terhadap stimulus atau objek kesehatan (yang dalam hal ini adalah masalah kesehatan, termasuk penyakit DM yang diderita seseorang), yang kemudian dalam proses selanjutnya akan melaksanakan atau mempraktekkan sesuai apa yang diketahuinya dan disikapi/ dinilainya baik untuk dilakukan ${ }^{17}$.

\section{Perbedaan Kadar Glukosa Darah Sewaktu Sebelum Dan Setelah Pendampingan Gizi}

Berdasarkan penelitian yang dilakukan diperoleh hasil bahwa terjadi perubahan sebesar 42,3\% kadar GDS terkendali setelah pendampingan gizi.

Hal ini sejalan dengan penelitian Norris $2002^{18}$ yaitu Manajemen diri sendiri dengan Edukasi diabetes telah dianggap penting dalam manajemen klinik individu.menunjukkan hasil bahwa hasil dari intervensi yang diberikan dapat mengontrol GHb darah pada responden yang diberikan edukasi $(0,76 \%)$ dari pada responden yang tidak diberi edukasi $(0,26 \%)$. Dan Dari hasil penelitian Miller CK, et all $2002^{19}$ menunjukkan bahwa responden melebihi pedoman untuk kontrol glikemik optimal pada pretest. Kelompok eksperimen memiliki perbaikan yang lebih besar dalam glukosa plasma puasa $(\mathrm{P}=0,05)$ dan hemoglobin terglikasi $(\mathrm{P}<0,01)$ daripada kelompok kontrol setelah diberikan edukasi gizi. Hal ini juga di dukung oleh penelitian Sharifirad et all $2009^{20}$ yaitu Hasil penelitian ini menunjukkan bahwa edukasi gizi dapat meningkatkan' pengetahuan pasien dan mengurangi glukosa darah puasa pasien. Kadar gula darah puasa yang diberikan edukasi gizi dan yang tidak diberikan edukasi gizi yaitu ada perbedaan signifikan dalam puasa glukosa darah dari dua kelompok dan dikurangi secara signifikan pada kelompok kasus dibandingkan dengan kelompok kontrol ( $\mathrm{p}<0,001)$.

Peningkatan pengontrolan terhadap kadar gula darah pasien ini disebabkan responden diberi alat bantu berupa print out materi DM Booklet. Berdasarkan penelitian tersebut tampak rata-rata pengetahuan subjek meningkat, patuh terhadap diet yang diberikan, anjuran aktifitas fisik dan minum obat. Hal ini disebabkan karena pemeriksaaan kadar gula darahnya didapatkan gratis sebelum dan setelah diberikan pendampingan sehingga pasien merasa antusias dalam melaksanakan diet yang diberikan. Hasil penelitian ini sejalan dengan yang dikemukakan Esti Setiyani yang menyatakan bahwa penyuluhan merupakan salah satu faktor terpenting dalam penanganan diabetes melitus khususnya dalam penerapan diit yang baik dimana dalam 
JKT, 2017;8(2):62-72. Studi Pengetahuan, Diet, Aktifitas Fisik, Minum Obat

Khartini Kaluku, Nurhaedar Jafar, Citrakesumasari

penyuluhan ini dapat diberikan pengetahuan dan ketrampilan dalam menerapkan diitnya dengan baik. Menurut Suyono 2005 , Pengetahuan tersebut akan menjadi titik tolak perubahan sikap dan gaya hidup mereka. Pada akhirnya yang menjadi tujuan penyuluhan adalah perubahan perilaku penyandang diabetes dan meningkatnya kepatuhan yang selanjutnya meningkatkan kualitas hidup ${ }^{21}$.

Dengan kontrol gula darah yang baik, risiko komplikasi makrovaskular dapat dikurangi. Kontrol gula darah ini tidak perlu terlalu ketat pada lansia mengingat risiko hipoglikemia pada lansia penderita DM. Target kontrol gula darah ditentukan oleh status kesehatan serta kemampuan fisik \& mental ${ }^{21}$.

\section{SIMPULAN}

Edukasi model pendampingan gizi sangat berpengatuh untuk meningkatkan pengetahuan dan kepatuhan responden terhadap diet, aktifitas fisik dan minum obat serta mengendalikan kadar glukosa darah.

\section{SARAN}

Kepada Puskesmas, agar dapat memberikan penyuluhan / konsultasi gizi agar pasien mengetahui tentang penatalaksanaan Diabetes Melitus sehingga pasien dapat merawat dirinya secara mandiri, tepat dan benar, serta melanjutkan program pendampingan gizi untuk memantau kadar gula darah pasien.

\section{UCAPAN TERIMA KASIH}

Ucapan terima kasih ditujukan pada BPPSDMK Kementerian Kesehatan sebagai pemberi dana riset. Seluruh pihak yang tidak disebutkan satu per satu yang banyak memberikan bantuan dan dukungan dalam menyelesaikan penelitian ini.

\section{RUJUKAN}

1. Waspadji, Sarwono dkk. Pedoman Diet Diabetes Melitus. Jakarta: FKUI; 2009.

2. Gupta, Vipin. Diabetes Mellitus In India. 2011; Terdapat pada:http://sancd.org/uploads/pdf/factsheet_diabetes.pdf . Diakses pada 3 Desember, 2011.

3. Suyono, S. Kecenderungan Peningkatan Pasien Diabetes Melitus. Jakarta: FKUI; 2011

4. Dalimartha, S. Ramuan Tradisionanl Untuk Pengobatan Diabetes Mellitus. Jakarta: Penebar Swadaya; 2005

5. Rusimah. Hubungan Tingkat Pendidikan Dan Pengetahuan Gizi Dengan Kepatuhan Diet Pada Penderita Diabetes Mellitus (Diabetisi) Di Ruang Rawat Inap Rsud Dr.H.Moch Ansari Saleh Banjarmasin Tahun 2010. (Skripsi). Banjarbaru; Sekolah Tinggi Ilmu Kesehatan Husada Borneo;2011

6. Amir A. Pengaruh Penyuluhan Model Pendampingan Terhadap. Perubahan Status Gizi Anak Usia 6-24 Bulan. (Thesis). Semarang. Universitas Diponegoro: 2011

7. Azwar S. Konsep dan Penerapan Metodologi Penelitian, Jakarta:PT. Rineka Cipta; 2007

8. Jazilah. Hubungan Tingkat Pengetahuan, Sikap dan Praktek (PSP) Penderita Diabetes Melitus dengan Kendali Kadar Glukosa Darah, Universitas Gadjah Mada. Jurnal Sains Kesehatan, 2003;16 (2) ; 413-22.

9. Aghamolaei. Effects Of A Health Education Program On Behavior, Hba1c And Health-Related Quality Of Life In Diabetic Patients.. Acta Medica Iranica, 2005;43(2); 89-94. Terdapat pada: http://journals.tums.ac.ir/upload_files/pdf/_/741.pdf .Diakses pada 23 April, 2012.

10. Abduracchim, Rijanti, dkk. Hubungan Tingkat Kepatuhan Diet Dengan Gula Reduksi Urin Dan Indeks Massa Tubuh Pada Diabetesi Yang Berobat Jalan Di Poliklinik Gizi RSUD Ulin Banjarmasin. Jurnal Kalimatan Scientiae, 2008;71 (4); 19-31. 
JKT, 2017;8(2):62-72. Studi Pengetahuan, Diet, Aktifitas Fisik, Minum Obat

Khartini Kaluku, Nurhaedar Jafar, Citrakesumasari

11. Moda, Putu, dkk. Pengaruh Penyuluhan Gizi Terhadap Kepatuhan Diet Pasien Diabetes Mellitus Di Poli Gizi Rsu Dr. Saiful Anwar Malang. Majalah Kesehatan FKUI; 2012. Terdapat pada: http://elibrary.ub.ac.id\%2Fbitstream\%2F123456789\%2F17867\%2F1\% 2FPengaruhpenyuluhan-gizi-terhadap-kepatuhan-diet-pasien-diabetus-mellitus-di-Poli Gizi-RS-Dr.-SaifulAnwarMalang.pdf. Diakses pada 29 Maret 2012.

12. Chabchoub, Blouza S, et al.The Effect Of Nutritional Education On The Food Intake Regulation Of The Young Diabetic,. Tunis Med. Jurnal NCBI, 2000; 78 (10);595-9.

13. Husain, Ahmad A. dkk. Pengendalian status gizi, kadar glukosa darah, dan tekanan darah melalui terapi gizi medis pada pasien diabetes mellitus (DM) tipe 2 rawat jalan di RSU Mataram NTB1. Jurnal Gizi Klinik Indonesia, 2010; 7( 2); 48-57.

14. Siddique, I et all,. Compliance to dietary counseling provided to patients wittype 2 diabetes at a tertiary care hospital Journal of Diabetology, 2010; 1(5);7. Terdapat pada: http://www.journalofdiabetology .org/Pages/Releases /PDFFiles/FirstIssue/OA-5-JOD-09002.pdf. Diakses pada 25 April ;2012

15. Sharifirad, Gholamreza et al.The Effectiveness Of Nutritional Education On The Knowledge Of Diabetic Patients Using The Health Belief Model. JRMS, 2009; 14 (1);1-6.

16. Waspadji, Sarwono dkk. Penatalaksanaan Diet Diabetes Melitus. Jakarta: FKUI: 2007

17. Notoatmodjo, S. Promosi Kesehatan dan Ilmu Perilaku. Jakarta. Rineka Cipta: 2007

18. Norris, Susan L., MD, MPH. Self-Management Education For Adults With Type 2 Diabetes A Meta-Analysis Of The Effect On Glycemic Control. Diabetes Care, 2002;25 (27):1159-71.

19. Miller CK et all. Nutrition Education Improves Metabolic Outcomes Among Older Adults With Diabetes Mellitus: Results From A Randomized Controlled Trial. National Center for Biotechnology Information, U.S. National Library of Medicine, NCBI, 2002; 34 (2) :252-9. Terdapat pada: http://www.ncbi.nlm.nih.gov/portal/utils/pageresolver.fcgi?recordid= 1332509445832587. Diakses pada 24 April: 2012

20. Wakhidiyah dan Intan Zainafree. Hubungan Antara Tingkat Pengetahuan, Sikap Dan Keikutsertaan Penyuluhan Gizi Dengan Perilaku Diit Pada Pasien Diabetes Melitus Tipe Ii Di Klinik Diabetes Melitus Rsj. Prof. Dr Soeroyo Magelang. Jurnal Kesmas, 2010;6(1);90-8

21. Kurniawan, Indra. Diabetes Melitus Pada Lansia. Klinik Usila Puskesmas Pangkalbalam, Pangkalpinang, Kepulauan Bangka Belitung. Majalah Kedokteran Indonesia, 2010; 60 (12);57684. 